\title{
The role of GSTA2 polymorphisms and haplotypes in breast cancer susceptibility: A case-control study in the Portuguese population
}

\author{
SUSANA N. SILVA ${ }^{1}$, ANA PAULA AZEVEDO ${ }^{3}$, VALDEMAR TEIXEIRA ${ }^{3}$, \\ JULIETA ESPERANÇA PINA ${ }^{2}$, JOSÉ RUEFF ${ }^{1}$ and JORGE FRANCISCO GASPAR ${ }^{1}$
}

\begin{abstract}
Departments of ${ }^{1}$ Genetics and ${ }^{2}$ Laboratory Medicine, Faculty of Medical Sciences, New University of Lisbon, Rua da Junqueira 96, 1349-008 Lisbon; ${ }^{3}$ Department of Clinical Pathology, Hospital de S. Francisco Xavier, Estrada do Forte do Alto do Duque 1495-005 Lisbon, Portugal
\end{abstract}

Received March 3, 2009; Accepted May 15, 2009

DOI: 10.3892/or_00000477

\begin{abstract}
Glutathione-S-transferases (GSTs) are a superfamily of phase II metabolizing enzymes that catalyse the detoxification of a large range of endogenous and exogenous toxic compounds, playing an important role in protecting cells against damage, through glutathione conjugation with electrophilic substances. Polymorphic variation in these enzymes that affect its activity seems to be related to individual susceptibility to various human diseases, including cancer. Of the GST super-family, the alpha class GSTs have commonly been described as one of the most versatile class, since it is responsible for detoxification of compounds such as bilirubin, bile acids and penicillin, thyroid and steroid hormones, allowing its solubilization and storage in the liver. Among the alpha class, GSTA1 and GSTA2 isoforms are the most widely expressed in human tissues. Additionally, these enzymes can catalyse conjugation of the nitrogen mustard group of alkylating anticancer drugs, some heterocyclic amines and $\alpha, \beta$-unsaturated aldehydes. Since some risk factors for increased breast cancer risk could be related to high production of reactive oxygen species during the metabolism of estrogens by catechol estrogens, or to the exposure to genotoxic compounds, and some of these toxic compounds are usually metabolized by GSTA2, we carried out a hospital based case-control study in a Caucasian Portuguese population (291 breast cancer patients without familiar history of breast cancer and 547 controls matched for age, sex and ethnicity) in order to evaluate the potential modifying role of three non-synonymous polymorphisms in
\end{abstract}

Correspondence to: Dr Jorge Francisco Gaspar, Department of Genetics, Faculty of Medical Sciences, New University of Lisbon, Rua da Junqueira 96, P-1349-008 Lisbon, Portugal

E-mail: jgaspar.gene@fcm.unl.pt

Key words: GSTA2 polymorphisms, genetic susceptibility, breast cancer the GSTA2 gene (P110S Ex 5+56C>T;, rs2234951; S112T Ex5+63G>C, rs2180314 and E210A Ex7+83A>C, rs6577) on the individual susceptibility to breast cancer. Our data show that the studied polymorphisms are in strong linkage disequilibrium, but no association was observed between individual GSTA2 polymorphisms and haplotypes and individual susceptibility to breast cancer.

\section{Introduction}

Breast cancer is the main type of female cancer (about 182,460 new cases are estimated by the American Cancer Society for 2008, in the USA) and the second leading cause of cancer death in women (1). However, the etiology of this disease remains elusive, even though it is known that for a substantial fraction of breast cancer cases, the age at the first child's birth, parity, menopausal age (i.e. reproductive and hormonal factors) and family history, are well-established risk factors.

The hereditary fraction of this pathology accounts for $5-10 \%$ of all breast cancer cases $(2,3)$, with BRCA1 and BRCA2 having been identified as the two main susceptibility genes from familial linkage studies (3). Even though mutations in these genes are highly associated with inherited predisposition, somatic mutations in these genes are rare in sporadic breast cancer cases.

The majority of the risk factors, mainly related to sporadic cases, point to an association with prolonged exposure to increased levels of estrogens $(4,5)$. Several epidemiological studies have been published showing that circulating estrogens may contribute to an increased risk of breast cancer. Furthermore, during the metabolism of estrogen some carcinogenic metabolites can be produced, such as cathecol estrogens (6-8). These metabolites could be responsible for an increased production of Reactive Oxygen Species (ROS), leading to disruption of cellular redox homeostasis $(7,8)$ and DNA lesions. It is postulated that the genotoxic consequences of the oxidative estrogen metabolism pathway is mitigated by conjugation reactions of the metabolites with phase II enzymes (8). Several enzymes are involved in the oxidative metabolism and conjugation of estrogens (7), suggesting a potential 
involvement of the polymorphic forms of their genes in breast cancer susceptibility.

One of the enzymatic families involved in Phase II metabolism $(6,7,9,10)$ is the highly polymorphic Glutathione S-Transferase (GSTs) super family which is responsible for carcinogen detoxification by conjugation with reduced glutathione (GSH) of numerous reactive metabolites, including by-products of oxidative stress (11) and metabolites generated through the oxidative estrogen metabolism pathway $(6,8)$. Some of these metabolites include estrogen quinones that undergo conjugation with GSH through the catalytic action of GSTP1. The formation of GSH-estrogen conjugates would reduce the level of estrogen quinones and thereby lower the potential for DNA damage (8).

The alpha class GSTs are strongly expressed in liver, kidney and adrenal tissue, and have commonly been described as one of the most versatile GST families, since it is responsible for GSH conjugation of compounds such as bilirubin, bile acids and penicillin, thyroid and steroid hormones, allowing their solubilization and storage in the liver (12). Additionally, the conjugation of the nitrogen mustard group of alkylating anticancer drugs, of some heterocyclic amines and $\alpha, \beta$-unsaturated aldehydes also leads to detoxification $(12,13)$. GSTA1 and GSTA2 are the most expressed alpha GSTs enzymes in the liver $(14,15)$, but they are also expressed in the human breast (15). There are few epidemiological studies relating the role of polymorphic alpha class GST in cancer susceptibility $(16,17)$, especially in breast cancer $(15)$. Since the Alpha family is involved in a wide range of roles that include steroid biosynthesis and providing protection against alkylating agents, polymorphic variations in these genes could be responsible for physiological consequences that could alter the susceptibility to disease and drug response (12). Two members of this class, GSTA1 and GSTA2 (usually co-expressed), catalyze the GSH conjugation of a wide variety of electrophiles, possess glutathione-dependent steroid isomerase activity, and glutathione-dependent peroxidase activity (14). The GSTA2 gene is believed to represent a major line of defense against oxidative stress (18).

To date, some epidemiological studies, regarding breast cancer susceptibility, have been carried out focusing on several polymorphic families of GSTs, mostly the GSTT1, GSTM1 and GSTP1 genes (6,19-26). Other GST families have been less studied, and there is a scarcity of results regarding the influence of the alpha class with breast cancer susceptibility. Since the GSTA2 gene is involved in the detoxification of metabolites associated with an increase risk to breast cancer, we carried out a hospital based case-control study in a Caucasian Portuguese population in order to evaluate the potential modifying role of the non-synonymous polymorphisms in the GSTA2 gene (P110S Ex 5+56C>T; rs2234951; S112T Ex5+63G>C, rs2180314 and E210A Ex $7+83 \mathrm{~A}>\mathrm{C}, \mathrm{rs6577})$ on the individual susceptibility to breast cancer.

\section{Materials and methods}

Study subjects. This study includes 291 Caucasian breast cancer female patients, recruited at São Francisco Xavier Hospital (Department of Laboratory Medicine), without previous history of neoplasic disease, thyroid pathology and blood transfusions. Histological diagnosis was confirmed in all the cases. The control population $(n=547)$ matched for sex and ethnicity, with no previous or concurrent malignant disease, was recruited at the same hospital where they were observed for non-malignant pathology. The anonymity of the patients and control population was guaranteed, and all studies were conducted with the written informed consent of all the individuals involved, obtained prior to blood withdrawal. Information on demographic characteristics, family history of cancer, lifestyle habits (e.g. smoking, alcohol drinking) was collected using a questionnaire administered by trained interviewers. Former smokers were defined as those who gave up smoking two years before cancer diagnosis or two years before the inclusion date as corresponding matched case. The response rate was higher than $95 \%$ for cases and controls.

DNA extraction. Blood samples of all patients and controls were collected into $10 \mathrm{ml}$ heparinized tubes and stored at $-20^{\circ} \mathrm{C}$ until use. Genomic DNA was obtained from $250 \mu 1$ of whole blood using a commercially available kit according to the manufacturer instructions (QIAamp DNA extraction kit; Qiagen, Hilden, Germany). Each DNA sample was stored at $-20^{\circ} \mathrm{C}$ until analysis.

Genotyping GSTA2 P110S, S112T and E210A gene polymorphisms. The genotyping of E210A polymorphism was determined by PCR-RFLP. The primers and PCR conditions for the polymorphic sites of this SNP are shown in Table I. This polymorphism results in either gain or loss of restriction sites, which therefore allowed the wild-type and variant alleles to be discriminated by RFLP after appropriate restriction enzyme digestion. After amplification, $10 \mu 1$ of each PCR products were digested with appropriate restriction enzymes and eletrophoresed in $4 \%$ agarose gel with ethidium bromide $(0.5 \mu \mathrm{g} / \mathrm{ml})$ for visualization under ultraviolet light. The expected product for each genotype of the tested SNP is shown in Table I. All the genotype determinations were carried out twice in independent experiments and inconclusive samples were reanalysed.

The P110S and S112T polymorphisms were genotyped by real-time PCR (AB7300) using TaqMan SNP Genotyping Assays from Applied Biosystems (ABI Assays reference: C_12027714_50 and C_22275149_30, respectively) according to the manufacturer's instructions. To carry out the allelic discrimination the DNA samples were quantified by PicoGreen dsDNA Quantification Reagent (Molecular Probes, Eugene, OR, USA) according to the manufacturer's recommendations.

Statistical analysis. Genotypic frequencies and the analysis of Hardy-Weinberg frequencies for the different polymorphisms studied, in the control and patients populations, were carried out using Mendel software (27).

The degree of linkage disequilibrium between the different SNPs expressed as D', and the haplotype estimation for the combination of the different SNPs studied were calculated using SNPStats software (28).

The $\chi^{2}$ test was used to evaluate the differences in genotype frequency, smoking status and alcohol consumption 
Table I. PCR-RFLP details for GSTA2 (E210A) polymorphism.

\begin{tabular}{llcccc}
\hline GSTA2 & Primer sequence & $\begin{array}{c}\text { Temp. } \\
\left({ }^{\circ} \mathrm{C}\right)\end{array}$ & $\begin{array}{c}\text { PCR } \\
\text { product } \\
(\mathrm{bp})\end{array}$ & $\begin{array}{c}\text { Effect on enzyme } \\
\text { restriction site }\end{array}$ & $\begin{array}{c}\text { Patterns after } \\
\text { enzyme restriction } \\
\text { enzyme digestion }\end{array}$ \\
\hline E210A & Forward 5'-CCAAggAAgCCTCCCATgCATg-3' & & & & AA: 163bp; \\
& Reverse 5'-gCTTCACAACAggCACAATCAACAC-3' & 62 & 163 & $\begin{array}{l}\text { A } \rightarrow \text { C creat one PaeI AC: } 163,140,23 b p ; \\
\text { restriction site }\end{array}$ & CC: $140,23 b p$ \\
\hline
\end{tabular}

Table II. General characteristics of breast cancer cases $(n=291)$ and control $(n=547)$ populations studied.

\begin{tabular}{|c|c|c|c|}
\hline Characteristics & Cases n $(\%)$ & Controls n (\%) & P-value \\
\hline \multicolumn{4}{|l|}{$\operatorname{Age}^{a, b}$} \\
\hline$\leq 30$ & $1(0.3)$ & $2(0.4)$ & \multirow{4}{*}{$0.921^{\mathrm{c}}$} \\
\hline $31-49$ & $68(23.4)$ & $120(21.9)$ & \\
\hline $50-69$ & $161(55.3)$ & $300(54.8)$ & \\
\hline$\geq 70$ & $61(21.0)$ & 125 (22.9) & \\
\hline \multicolumn{4}{|l|}{ Smoking habits } \\
\hline Never and former & 254 (87.9) & 490 (91.6) & \multirow{3}{*}{$0.087^{\mathrm{c}}$} \\
\hline Current & $35(12.1)$ & $45(8.4)$ & \\
\hline Missing & 2 & 12 & \\
\hline \multicolumn{4}{|l|}{ Alcohol habits } \\
\hline Never & $221(76.2)$ & $441(82.6)$ & \multirow{4}{*}{$<0.0001^{\mathrm{c}}$} \\
\hline Social & $25(8.6)$ & $59(11.0)$ & \\
\hline Regular & $44(15.2)$ & $34(6.4)$ & \\
\hline Missing & 1 & 13 & \\
\hline
\end{tabular}

${ }^{a}$ Age of cases at diagnosis; ${ }^{b}$ age of control population at the time of diagnosis for the matched case; ${ }^{c}$ cases vs. control group; ${ }^{d}$ see Materials and methods.

distributions between cases and controls. The KolmogorovSmirnov test was used in order to verify the normality of the continuous variables (e.g. age) and the Levene test was used to analyse the homogeneity of variances.

The crude and adjusted odds ratio (OR) and the corresponding $95 \%$ confidence intervals $(\mathrm{CI})$ were calculated using unconditional multiple logistic regression. The model for adjusted OR included terms for age at diagnosis $(\leq 30,31-49$, 50-69 and $\geq 70$ years), the lower age group being the reference class; alcohol consumption (never, social and regular drinkers) non-drinkers being the reference group, and smoking habits (smokers/non smokers), non-smokers being the reference group. All analyses were performed with an SPSS statistical package (version 15.0) (SPSS Inc. Chicago, IL).

\section{Results}

Two-hundred and ninety-one breast cancer patients and 547 age-matched controls in this Portuguese case-control study were included. The main characteristics (age, smoking and alcohol habits) for both populations are shown in Table II. No significant differences for age and smoking habits were found between cases and controls. However, alcohol drinkers are more prevalent among breast cancer patients than in the control population.

We included in this study 3 SNPs present in the GSTA2 gene (P110S, S112T and E210A), all non-synonymous. All the SNPs are in Hardy-Weinberg equilibrium and in Table III are depicted the Minor Allele Frequency (MAF), and genotype frequencies in both populations. MAF values obtained were in accordance with the ones reported in the HapMap project (http://www.hapmap.org/). The data available in the literature in Caucasian populations, the genotype frequencies for the GSTA2 S112T polymorphism and the values reported in these studies are ambiguous, two of them are in agreement with the data obtained in this study $(16,29)$, while further two studies report different frequencies $(17,30)$. The SNP frequencies in control and cancer population are not significantly different and the crude and adjusted ORs associated with each polymorphism are not significantly different (Table III), suggesting that these polymorphisms are not associated with breast cancer susceptibility. The ORs associated with the different SNPs studied after stratification for different breast cancer status, that could be relevant as 
Table III. Genotype distribution and breast cancer risk to the polymorphisms studied (GSTA2 P110S, S112T and E210A) in cases and control population.

\begin{tabular}{|c|c|c|c|c|c|c|}
\hline \multirow{2}{*}{ Genotype } & \multirow{2}{*}{ Cases n $(\%)$} & \multirow{2}{*}{ Controls n $(\%)$} & \multicolumn{2}{|c|}{ MAF } & \multirow{2}{*}{ Crude OR (95\% CI) } & \multirow{2}{*}{ Adjusted OR $(95 \% \mathrm{CI})^{\mathrm{a}}$} \\
\hline & & & Cases & Controls & & \\
\hline \multicolumn{7}{|c|}{$\mathrm{P} 110 \mathrm{~S}(\mathrm{Ex} 5+56 \mathrm{C}>\mathrm{T})$} \\
\hline $\mathrm{CC}$ & $265(91.7)$ & $505(92.8)$ & \multirow{5}{*}{\multicolumn{2}{|c|}{ T: $0.0415 \pm 0.0083$ T: $0.0358 \pm 0.0056$}} & 1 (Reference) & 1 (Reference) \\
\hline CT & $24(8.3)$ & $39(7.2)$ & & & $1.173(0.690-1.992)$ & $1.218(0.705-2.104)$ \\
\hline & & & & & & \\
\hline TT & - & - & & & & \\
\hline Missing & 2 & 3 & & & & \\
\hline \multicolumn{7}{|c|}{$\mathrm{S} 112 \mathrm{~T}(\mathrm{Ex} 5+63 \mathrm{G}>\mathrm{C})$} \\
\hline GG & $92(31.8)$ & $155(28.5)$ & \multirow{5}{*}{\multicolumn{2}{|c|}{ C: $0.4291 \pm 0.0206$ C: $0.4567 \pm 0.0151$}} & 1 (Reference) & 1 (Reference) \\
\hline GC & $146(50.5)$ & $280(51.6)$ & & & $0.878(0.634-1.218)$ & $0.873(0.625-1.219)$ \\
\hline & & & & & & \\
\hline $\mathrm{CC}$ & $51(17.6)$ & $108(19.9)$ & & & $0.796(0.522-1.212)$ & $0.770(0.501-1.184)$ \\
\hline Missing & 2 & 4 & & & - & - \\
\hline \multicolumn{7}{|c|}{$\mathrm{E} 210 \mathrm{~A}(\mathrm{Ex} 7+83 \mathrm{~A}>\mathrm{C})$} \\
\hline AA & $257(88.6)$ & $485(88.7)$ & \multirow{5}{*}{ C: $0.0569 \pm 0.0096$} & \multirow{5}{*}{ C: $0.0576 \pm 0.007$} & 1 (Reference) & 1 (Reference) \\
\hline $\mathrm{AC}$ & $33(11.4)$ & $61(11.2)$ & & & $1.017(0.649-1.594)$ & $1.008(0.635-1.601)$ \\
\hline $\mathrm{CC}$ & $0(0)$ & $1(0.2)$ & & & ND & ND \\
\hline $\mathrm{AC}+\mathrm{CC}$ & 33 & 62 & & & $1.001(0.639-1.567)$ & $0.989(0.623-1.569)$ \\
\hline Missing & - & - & & & - & - \\
\hline
\end{tabular}

aORs were adjusted for: age at diagnosis $(\leq 30,31-49,50-69$ and $\geq 70)$, the lower age group being the reference class; alcohol consumption (never, social and regular drinkers), never drinkers being the reference class, and smoking habits (smokers/non-smokers), non-smokers being the reference class.

Table IV. Linkage disequilibrium coefficient $\mathrm{D}^{\prime}$ between the three studied SNPs.

\begin{tabular}{lccc}
\hline SNP & P110S & S112T & E210A \\
\hline P110S & - & 0.8992 & 0.9665 \\
S112T & - & - & 0.9696 \\
E210A & - & - & - \\
\hline
\end{tabular}

potential risk factors (i.e. breast feeding, menopausal age, menarche age, parity, age at first full-term pregnancy), were undertaken and did not reveal any potential association with disease either (data not shown). The linkage disequilibrium analysis was determined using SNPStats software, and demonstrates that all SNPs evaluated in this study are in linkage disequilibrium, measured by $\mathrm{D}^{\prime}$ values as depicted in Table IV.

The combination of the different alleles of the GSTA2 gene could potentially generate eight different haplotypes, but haplotype estimation with the data obtained in our study only reveal the existence of six different haplotypes (Table V), four of them were previously described by Tetlow et al in Australian, Bantu African, Creole African and Chinese
Table V. GSTA2 haplotype frequencies in Portuguese population estimated by SNPStats software.

\begin{tabular}{lcr}
\hline & \multicolumn{2}{c}{ Haplotype frequencies } \\
\cline { 2 - 3 } Haplotype estimation & Cases & Controls \\
\hline GSTA2 (P110; S112; E210) & 0.5713 & 0.5387 \\
GSTA2 $(\mathrm{P} 110 ; \mathrm{S} 112 ; \mathrm{A} 210)^{\mathrm{a}}$ & $\mathrm{NA}$ & 0.00140 \\
GSTA2 (P110; T112; E210) & 0.3303 & 0.3679 \\
GSTA2 $(\mathrm{S} 110 ; \mathrm{S} 112 ; \mathrm{E} 210)^{\mathrm{a}}$ & $\mathrm{NA}$ & 0.003 \\
GSTA2 & 0.0567 & 0.0562 \\
GSTA2 (S110; T112; A210) & 0.0418 & 0.0328 \\
\hline
\end{tabular}

${ }^{\text {a}}$ Haplotypes also identified by Tetlow et al (13).

populations $(12,13)$. From the different haplotypes generated by the GSTA2 non-synonymous polymorphism two of them (P110; S112; E210 and P110; T112; E210) (see Table V) have a cumulative frequency higher than $90 \%$ in both populations studied, and each one with a similar frequency in both populations. Accordingly, the data obtained concerning the 
role of these haplotypes in breast cancer susceptibility do not reveal any significant association with the disease (data not show).

\section{Discussion}

There is a lack of data on the role of GSTA2 polymorphisms in human cancers. The data published until now has been mainly focused on GSTA2 genomic organization, its expression in different tissues (31-33) and functional characterization of the GSTA2 polymorphisms $(12,13,17,34,35)$.

Several polymorphisms in GSTA2 gene were described by Tetlow et al in three different ethnic populations. Some functional studies developed to evaluate the protein activity of variants generated by multiple polymorphisms, report in all but one haplotype [GSTA2 (S110; S112; E210)] no significant discrepancy in protein activity when compared with the more frequent haplotype [GSTA2 (P110; S112; E210)] $(12,13,17)$. In fact, the variant form has a lower activity towards the conjugation of several substrates, such as Cumene hydroperoxide (12), suggesting that individuals with the S110 variant may have an increased susceptibility to disease related with oxidative stress. Additionally, the GSTA2 is also involved in the isomerization of $\Delta^{5}$-androstene-3,17dione, a precursor of several steroid hormones, such as progesterone. The variant form of GSTA2 S110 also shows a lower activity towards this substrate, suggesting that individuals carrying this variant might have lower levels of steroid hormones. These studies structurally characterized the polymorphisms of human glutathione S-transferase alpha class, showing that $\mathrm{S} 112 \mathrm{~T}$ and $\mathrm{E} 210 \mathrm{~A}$ amino acid residues are not in the active site. The change S112T is conservative (both residues are polar non-charged) and did not show a dramatic effect on protein structure, while E210A is nonconservative (A residue is a small polar and $\mathrm{E}$ a large acidic residue), although this residue position could have a slight effect on protein function. Concerning the P110S it was shown that the substitution of a hydrophobic residue, nonpolar (Pro), by a hydrophilic, uncharged polar residue (Ser), might both reduce the rigidity of the active site related to the loss of a structural residue, and increase hydrophilicity (12).

We performed a comprehensive study to analyze the possible role of 3 common non-synonymous polymorphisms (P110S; S112T; E210A) of GSTA2 gene in the genetic susceptibility to breast cancer, which, to our knowledge, is the first study relating breast cancer with these polymorphisms. However, our results did not reveal any association of the different GSTA2 polymorphisms evaluated and individual susceptibility to breast cancer (Table III). These results might be explained by the fact that the S112T and E210A polymorphisms do not lead to a significant decrease in the enzyme catalytic activity, and the polymorphism associated with changes in catalytic activity (GSTA2 P110S), is only observed in heterozygosity, and with a frequency lower than $10 \%$ in both populations (cases and controls) (Table III). Regarding the molecular-epidemiological studies concerning GSTA2 polymorphisms, no association between the GSTA2 (S112T) polymorphism and the risk of colorectal cancer, malignant pleural mesothelioma $(29,30)$ and prostate cancer (17) was described, but the variant allele of this poly- morphism seems to be associated with an increased risk of lung cancer (16). Additionally, our study reveals that all SNPs studied are in linkage disequilibrium. Through the combination of the different allelic variants of GSTA2 nonsynonymous polymorphisms, we obtained six different haplotypes in our populations (see Table V), which is in agreement with the data reported in previous studies $(12,13)$. However, the results showed consistent differences on haplotype frequencies in other populations $(12,13)$, that could be explained based on the basis of ethnic differences between populations.

Recent data from cancer studies have linked aberrant expression of GST isozymes with the development and expression of resistance to a variety of chemicals, especially the ones used as anticancer therapies. Studies in tumor tissues and chemotherapeutic-resistant tumor cell lines have shown overexpression of these enzymes $(9,36)$. Furthermore, studies in normal and cancer human breast tissue, showed that in most cases, the average level of GSTs was substantially elevated in the cancer tissues when compared with normal tissue, providing a plausible mechanism for the variable response to treatment (33).

Even though our data suggest that GSTA2 polymorphisms are not associated with individual susceptibility to breast cancer risk, we cannot exclude that other SNPs in other genes associated with the detoxification might be involved in susceptibility to breast cancer. Additionally, we also cannot exclude that these polymorphisms might be associated with other aspects of oncologic disease such as drug resistance/ patient survival, but further studies are required to evaluate this effect.

\section{Aknowledgements}

We wish to thank Luísa Manso Oliveira, Lylliane Luz, Silvia Morgado Amaro and Maria Catarina Soveral for technical support. Center for Research in Human Molecular Genetics (CIGMH), Projects POCTI/QUI/57110/2004 from Fundação da Ciência e Tecnologia (FCT) and Fundação Calouste Gulbenkian (Grant 69405) support our current research. The PhD grant SFRH/BD/17828/2004 from FCT is also acknowledged.

\section{References}

1. Jemal A, Siegel R, Ward E, Hao Y, Xu J, Murray T and Thun MJ: Cancer statistics, 2008. CA Cancer J Clin 58: 71-96, 2008.

2. Bradbury AR and Olopade OI: Genetic susceptibility to breast cancer. Rev Endocr Metab Disord 8: 255-267, 2007.

3. Dapic V, Carvalho MA and Monteiro AN: Breast cancer susceptibility and the DNA damage response. Cancer Control 12: 127-136, 2005.

4. Silva SN, Cabral MN, Bezerra de CG, Pires M, Azevedo AP, Manita I, Pina JE, Rueff J and Gaspar J: Breast cancer risk and polymorphisms in genes involved in metabolism of estrogens (CYP17, HSD17beta1, COMT and MnSOD): possible protective role of MnSOD gene polymorphism Val/Ala and Ala/Ala in women that never breast fed. Oncol Rep 16: 781-788, 2006.

5. Cheng TC, Chen ST, Huang CS, Fu YP, Yu JC, Cheng CW, Wu PE and Shen CY: Breast cancer risk associated with genotype polymorphism of the catechol estrogen-metabolizing genes: a multigenic study on cancer susceptibility. Int J Cancer 113: 345-353, 2005. 
6. Torresan C, Oliveira MM, Torrezan GT, de Oliveira SF Abuazar CS, Losi-Guembarovski R, Lima RS, Urban CA, Cavalli IJ and Ribeiro EM: Genetic polymorphisms in oestrogen metabolic pathway and breast cancer: a positive association with combined CYP/GST genotypes. Clin Exp Med 8: 65-71, 2008 .

7. Yager JD: Endogenous estrogens as carcinogens through metabolic activation. J Natl Cancer Inst Monogr pp67-73, 2000.

8. Crooke PS, Ritchie MD, Hachey DL, Dawling S, Roodi N and Parl FF: Estrogens, enzyme variants, and breast cancer: a risk model. Cancer Epidemiol Biomarkers Prev 15: 1620-1629, 2006.

9. McIlwain CC, Townsend DM and Tew KD: Glutathione Stransferase polymorphisms: cancer incidence and therapy. Oncogene 25: 1639-1648, 2006.

10. Unlu A, Ates NA, Tamer L and Ates C: Relation of glutathione S-transferase T1, M1 and P1 genotypes and breast cancer risk. Cell Biochem Funct 26: 643-647, 2008.

11. Hayes JD, Flanagan JU and Jowsey IR: Glutathione transferases. Annu Rev Pharmacol Toxicol 45: 51-88, 2005.

12. Tetlow N and Board PG: Functional polymorphism of human glutathione transferase A2. Pharmacogenetics 14: 111-116, 2004.

13. Tetlow N, Liu D and Board P: Polymorphism of human alpha class glutathione transferases. Pharmacogenetics 11: 609-617, 2001 .

14. Coles BF and Kadlubar FF: Human alpha class glutathione Stransferases: genetic polymorphism, expression, and susceptibility to disease. Methods Enzymol 401: 9-42, 2005

15. Ahn J, Gammon MD, Santella RM, Gaudet MM, Britton JA, Teitelbaum SL, Terry MB, Neugut AI, Eng SM, Zhang Y, Garza C and Ambrosone CB: Effects of glutathione Stransferase A1 (GSTA1) genotype and potential modifiers on breast cancer risk. Carcinogenesis 27: 1876-1882, 2006.

16. Gemignani F, Landi S, Szeszenia-Dabrowska N, Zaridze D, Lissowska J, Rudnai P, Fabianova E, Mates D, Foretova L, Janout V, Bencko V, Gaborieau V, Gioia-Patricola L, Bellini I, Barale R, Canzian F, Hall J, Boffetta P, Hung RJ and Brennan P: Development of lung cancer before the age of 50: the role of xenobiotic metabolizing genes. Carcinogenesis 28: 1287-1293, 2007.

17. Ning B, Wang C, Morel F, Nowell S, Ratnasinghe DL, Carter W, Kadlubar FF and Coles B: Human glutathione S-transferase A2 polymorphisms: variant expression, distribution in prostate cancer cases/controls and a novel form. Pharmacogenetics 14 : $35-44,2004$

18. Tetlow N, Coggan M, Casarotto MG and Board PG: Functional polymorphism of human glutathione transferase A3: effects on xenobiotic metabolism and steroid biosynthesis. Pharmacogenetics 14: 657-663, 2004.

19. Steck SE, Gaudet MM, Britton JA, Teitelbaum SL, Terry MB, Neugut AI, Santella RM and Gammon MD: Interactions among GSTM1, GSTT1 and GSTP1 polymorphisms, cruciferous vegetable intake and breast cancer risk. Carcinogenesis 28: 1954-1959, 2007.

20. Saxena A, Dhillon VS, Raish M, Asim M, Rehman S, Shukla NK, Deo SV, Ara A and Husain SA: Detection and relevance of germline genetic polymorphisms in glutathione S-transferases (GSTs) in breast cancer patients from northern Indian population. Breast Cancer Res Treat (In press).

21. Lee SA, Fowke JH, Lu W, Ye C, Zheng Y, Cai Q, Gu K, Gao YT, Shu XO and Zheng W: Cruciferous vegetables, the GSTP1 Ile105Val genetic polymorphism, and breast cancer risk. Am J Clin Nutr 87: 753-760, 2008

22. Syamala VS, Sreeja L, Syamala V, Raveendran PB, Balakrishnan R, Kuttan R and Ankathil R: Influence of germline polymorphisms of GSTT1, GSTM1, and GSTP1 in familial versus sporadic breast cancer susceptibility and survival. Fam Cancer 7: 213-220, 2008.
23. Vogl FD, Taioli E, Maugard C, Zheng W, Pinto LF, Ambrosone C, Parl FF, Nedelcheva-Kristensen V, Rebbeck TR, Brennan P and Boffetta P: Glutathione S-transferases M1, T1, and P1 and breast cancer: a pooled analysis. Cancer Epidemiol Biomarkers Prev 13: 1473-1479, 2004

24. Zheng T, Holford TR, Zahm SH, Owens PH, Boyle P, Zhang Y, Zhang B, Wise JP Sr, Stephenson LP and li-Osman F: Glutathione S-transferase M1 and T1 genetic polymorphisms, alcohol consumption and breast cancer risk. Br J Cancer 88: 58-62, 2003.

25. Zheng W, Wen WQ, Gustafson DR, Gross M, Cerhan JR and Folsom AR: GSTM1 and GSTT1 polymorphisms and postmenopausal breast cancer risk. Breast Cancer Res Treat 74: 9-16, 2002 .

26. Maugard CM, Charrier J and Bignon YJ: Allelic deletion at glutathione S-transferase M1 locus and its association with breast cancer susceptibility. Chem Biol Interact 111-112: 365-375, 1998.

27. Lange K, Cantor R, Horvath S, Perola M, Sabatti C, Sinsheimer J and Sobel E: Mendel version 4.0: A complete package for the exact genetic analysis of discrete traits in pedigree and population data sets. Am J Hum Genet 69 (Suppl): A1886, 2001.

28. Sole X, Guino E, Valls J, Iniesta R and Moreno V: SNPStats: a web tool for the analysis of association studies. Bioinformatics 22: $1928-1929,2006$

29. Landi S, Gemignani F, Moreno V, Gioia-Patricola L, Chabrier A, Guino E, Navarro M, de Oca J, Capella G and Canzian F: A comprehensive analysis of phase I and phase II metabolism gene polymorphisms and risk of colorectal cancer. Pharmacogenet Genomics 15: 535-546, 2005.

30. Landi S, Gemignani F, Neri M, Barale R, Bonassi S, Bottari F, Canessa PA, Canzian F, Ceppi M, Filiberti R, Ivaldi GP, Mencoboni M, Scaruffi P, Tonini GP, Mutti L and Puntoni R: Polymorphisms of glutathione-S-transferase M1 and manganese superoxide dismutase are associated with the risk of malignant pleural mesothelioma. Int J Cancer 120: 2739-2743, 2007.

31. Coles BF, Anderson KE, Doerge DR, Churchwell MI, Lang NP and Kadlubar FF: Quantitative analysis of interindividual variation of glutathione S-transferase expression in human pancreas and the ambiguity of correlating genotype with phenotype. Cancer Res 60: 573-579, 2000.

32. Coles BF, Morel F, Rauch C, Huber WW, Yang M, Teitel CH, Green B, Lang NP and Kadlubar FF: Effect of polymorphism in the human glutathione S-transferase A1 promoter on hepatic GSTA1 and GSTA2 expression. Pharmacogenetics 11: 663-669, 2001.

33. Kelley MK, Engqvist-Goldstein A, Montali JA, Wheatley JB Schmidt DE Jr and Kauvar LM: Variability of glutathione Stransferase isoenzyme patterns in matched normal and cancer human breast tissue. Biochem J 304: 843-848, 1994.

34. Guy CA, Hoogendoorn B, Smith SK, Coleman S, O'Donovan MC and Buckland PR: Promoter polymorphisms in glutathione-Stransferase genes affect transcription. Pharmacogenetics 14: 45-51, 2004.

35. Morel F, Rauch C, Coles B, Le FE and Guillouzo A: The human glutathione transferase alpha locus: genomic organization of the gene cluster and functional characterization of the genetic polymorphism in the hGSTA1 promoter. Pharmacogenetics 12: 277-286, 2002.

36. Dialyna IA, Arvanitis DA and Spandidos DA: Genetic polymorphisms and transcriptional pattern analysis of CYP1A1, AhR, GSTM1, GSTP1 and GSTT1 genes in breast cancer. Int J Mol Med 8: 79-87, 2001. 